\title{
НОРМАТИВНА ГРОШОВА ОЦНКА ЗЕМЕЛЬ ЯК МЕХАНІЗМ СТИМУЛЮВАННЯ РОЗВИТКУ ГРОМАД
}

Малиновська Н. Л., канд. іст. наук, доцент, Інститут державного управління, Чорноморський національний університет імені Петра Могили, м. Миколаїв, Україна.

Штирьов О. М., канд. наук з держ. упр., доцент, Інститут державного управління, Чорноморський національний університет імені Петра Могили, м. Миколаїв, Україна.

Головащенко Н. Г., заступник начальника відділу ринку та оцінки земель Головного управління Держгеокадастру у Миколаївській області, м. Миколаїв, Україна.

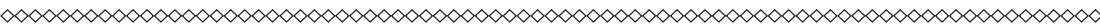

У статті розглянуто нормативну грошову оцінку земель як один із механізмів стимулювання розвитку громад в умовах децентралізації, в умовах формування ринку землі.

Акцентовано увагу на важливості проведення оціночних робіт з грошової оцінки земель, оскільки ие є економічний механізм земельних відносин, приватизації земельних ділянок, земельно-іпотечного кредитування, оподаткування та становлення ринку землі в цілому. Зазначено, щзо проблемність ситуації полягає у тому, щзо всі суб'єкти земельних відносин погоджуються з тим, що земля має свою иіну, але існують розбіжності у методичних підходах до нормативно - грошової оцінки, а отже і у практичній реалізації. Привернуто увагу до того, щзо продуктивні властивості земельного простору визначаються його географічним розташуванням, а отже, вже завдяки цььому, за умов розумного використання повинні сприяти сочіально-економічному розвитку громади.

Проаналізовано сутність, зміст та сфери застосування нормативної грошової оцінки земельної ділянки, простежено регуля- 
торний та стимулюючий характер нормативної грошової оцінки земель на рівні громади, наведено інформачію щзодо переконливості значення нормативно - грошової очінки для громади на прикладі селища Святомиколаївка Вітовського району Миколаївської області, узагальнено досвід роботи Головного управління Держгеокадастру у Миколаӥвській області щуодо нормативно - грошової оцінки.

Звертається увага на сочіально-економічне значення нормативно - грошової оцінки, оскільки обтрунтованість оцінки земельних ділянок захищатиме інтереси мільйонів громадян, які набули або набувають у власність земельні ділянки.

На прикладі технічної документащії з нормативної грошової оиінки селища Святомиколаївка Вітовського району Миколаӥвської області показано переваги виконання робіт з нормативної грошової оцінки земель з різних аспектів, розширено уявлення про регуляторний та стимулюючий характер нормативно - грошової очінки, про ї̈ практичне значення, про важливість актуалізації нормативно грошової очінки.

Як висновок, зазначено, щзо з метою активізації оціночної діяльності та актуалізації нормативної грошової оцінки земель різного призначення варто: посилити роз'яснювальну роботу серед учасників земельного ринку щодо необхідності та доцільності нормативної грошової оцінки з метою прискорення реформ, у тому числі стимулювання економічного розвитку регіонів України, сочіальноекономічного розвитку громад; оперативно та зрозуміло висвітлювати діяльність органів державної влади та органів місчевого самоврядування щзодо земельної політики.

Ключові слова: нормативна грошова оцінка земель, актуалізація нормативної грошової оцінки, технічна документація з нормативної громової очінки земель, селище Святомиколаӥвка Вітовського району Миколаївської області, стимулювання розвитку громад, Головне управління Держгеокадастру у Миколаӥвській області, органи місиевого самоврядування. 
Постановка проблеми у загальному вигляді. Важливість проведення робіт з грошової оцінки земель за останній час зростає, а сфери iіi застосування розширюються. Грошова оцінка земель розглядається як економічний механізм земельних відносин, приватизації земельних ділянок, земельно-іпотечного кредитування, оподаткування та становлення ринку землі. Проблемність ситуації полягає у тому, що всі суб'єкти земельних відносин погоджуються 3 тим, що земля має свою ціну, але існують розбіжності у методичних підходах до оцінки, а отже і у практичній реалізації.

Наукові погляди на процес формування методики оцінки земель та ринкового обігу земель, є, з одного боку різними, але 3 іншого, грошова оцінка земель розглядається як основа здійснення передачі землі у власність, спадщину, під заставу, в оренду, отримання банківського кредиту, визначення ставок земельного податку, обсягу внеску при створенні акціонерних товариств, об'єднань, кооперативів, ціноутворення, умовою розвитку сільських територій, а отже, $\epsilon$ ключовою відповідно до вимог часу.

Розглядаючи землю як активний елемент виробництва, розуміємо, що продуктивні властивості земельного простору визначаються його географічним розташуванням, а отже, вже завдяки цьому, за умов розумного використання повинні сприяти соціально-економічному розвитку громади.

Аналіз останніх досліджень і публікацій. Методичні підходи щодо оцінки землі, види оцінок та їх теоретичне й практичне значення розглядаються в працях О. Драпіковського, І. Іванової, Ю. Дехтяренко, Н. Мехеди, Ш. Бекашева, Д. Добряка, П. Кулинича; необхідність удосконалення нормативної грошової оцінки земель сільськогосподарського призначення висвітлено у роботах В. Месель-Веселяка, А. Мартина, Г. Дудича; правові аспекти оцінки землі досліджено А. Окрепкою, А. Федун; визначення вартості територій і оцінки земель населених пунктів України розкрито у дослідженнях Ю. Палехи, В. Носіка, Т. Свсюкова; проблемам державного регулювання використання земельних ресурсів присвячено праці С. Балюка, О. Будзяка, І. Гаражи, О. Гнаткович, В. Данкевич, А. Дібрової, В. Сташенко, Т. Титаренко, Г. Шарий, М. Шульги, Д. Маліхіна, істо- 
ричні та методични аспекти оцінки земель в Україні висвітлюють Н. Солов'яненко, В. Кілочко; геоінформаційне забезпечення нормативної грошової оцінки є предметом уваги К. Мамонова, А. Ачкасова, Т. Анопрієнко, О. Степенко.

Але з'являються нові проблемні питання та виникають нові потреби для оптимізації практики нормативної грошової оцінки землі як фактору стимулювання розвитку громад та створення підгрунття для іiі реалізації.

Формулювання цілей статті (постановка завдання). В процесі дослідження було поставлено наступні завдання:

- проаналізувати сутність, зміст та сфери застосування нормативної грошової оцінки земельної ділянки;

- простежити регуляторний та стимулюючий характер нормативної грошової оцінки земель на рівні громади.

Виклад основного матеріалу дослідження. Вартісний орієнтир цінності землі використовується як у системі публічного управління земельними ресурсами, так і при набутті та здійсненні права власності, інших прав на земельні ділянки. В Україні практика грошової оцінки землі здійснюється у формах нормативної і експертної (ринкової) оцінки [28], і як зазнчають фахівці [1, 7, 8, 15, 23], є не зовсім зрозумілою та виваженою, що ускладнює практичну роботу 3 оціночної діяльності земель різного призначення. У той час, як точна і повна оцінка земельних ресурсів є одним із важливих засобів забезпечення збереження та раціонального використання землі як основного національного багатства, як механізма стимулювання економічного розвитку регіонів.

Місцевий економічний розвиток - це діяльність підприємств, суб'єктів господарювання на території регіону, органів місцевого самоврядування та інших зацікавлених сторін, що спрямована на примноження економічних ресурсів громади, отримання позитивного соціально-економічного ефекту.

Відомо, що визначальними чинниками стратегії стимулювання розвитку регіонів $\epsilon$ : підвищення продуктивності праці та зниження витрат виробництва; розвиток галузей промисловості (що забезпечують економічну безпеку); нарощування та використання еконо- 
мічного (виробничого, наукового, фінансового та інтелектуального) потенціалу регіону; формування організаційних форм використання елементів продуктивних сил, орієнтованих на виробництво продукції з підвищеною доданою вартістю; стимулювання створення валового регіонального продукту, який визначається як різниця між вартістю вироблених і вартістю повністю спожитих у процесі виробництва товарів і послуг.

Досягнення стабільного місцевого економічного зростання тісно пов'язане 3 проведенням нормативної грошової оцінки земель, оскільки нормативно-грошова оцінка є також важливим джерелом наповнення бюджетів різних рівнів, консолідації бюджетних коштів для фінансування заходів щодо збереження родючості грунтів та охорони земель, виконання робіт з землеустрою тощо.

Фахівці зазначають, що нормативна грошова оцінка як механізм стимулювання регіонів України, має свої переваги порівняно 3 іншим підходами до землі як природного ресурсу, а саме:

- це база для встановлення обгрунтованих платежів за землю, зокрема, розрахунку орендної плати та визначення земельного податку;

- це основа для визначення плати за оренду земельних ділянок, розміру земельного податку, державного мита при міні, спадкуванні та даруванні ділянок тощо;

- нормативно грошову оцінку проводять на землях усіх категорій та форм власності за рішенням органу виконавчої влади або органу місцевого самоврядування, чи на підставі договору;

- нормативна грошова оцінка дозволить врахувати усі необхідні норми для того, щоб сформувати оновлену систему оподаткування у земельній сфері;

- нові відомості про оцінку земельних ділянок вносяться до Державного земельного кадастру й стають доступними для землевласників і землекористувачів.

У «Національній доповіді щодо завершення земельної реформи», 2015 (за наук. ред. Л.Новаковського) підкреслено, що «земельна реформа стала одним із найважливіших напрямів суспільних змін, що відбуваються в державі після набуття нею незалежності». 
За цей час ліквідовано монополію держави на земельну власність, сформовано приватну власність, запроваджено платність землекористування, створено нові аграрні формування ринкового типу, почав діяти ринок земель, в основному напрацьовано систему ринкового земельного закодавства [14].

Приєднуємось до думки К. Мамонова, А. Ачкасова та А. Анопрієнко, що «грошова оцінка земель $є$ важливим елементом здійснення земельної та економічної реформ в Україні та виступає інтегральною характеристикою кількісних, якісних, економічних, правових, регіональних та інших показників земельних ділянок і створює підгрунтя для впровадження механізму щодо оподаткування земель та справляння інших платежів у процесі цивільного обігу земельних ділянок» [7].

Звернемо увагу ще на один аспект нормативно грошової оцінки. За своїм змістом грошову оцінку земель відносять до задач геоінформаційного (просторового) аналізу $[7,26]$, оскільки іiі виконання потребує визначення впливу факторів регіонального, зонального та локального місцерозташування земельних ділянок на території населеного пункту, які мають кількісні характеристики, просторову прив'язку та просторові відношення.

При розробці проектів грошової оцінки земель використовуються їх кількісні та якісні характеристики, карти (схеми) бонітування грунтів, кадастрового зонування, генеральні плани та проекти планування і забудови населених пунктів, їх історико-культурного, функціонального, санітарно-екологічного, інженерно-геологічного та іншого зонування [7, 26].

Значна кількість показників, їх просторова прив'язка та різноманітність джерел потребує застосування геоінформаційних технологій і геоінформаційних систем (ГІС) у процесі розробки проектів грошової оцінки земель та їх практичного застосування усіма суб'єктами управління та користування земельними ресурсами: регіональними та місцевими органами Держземагентства, державної податкової адміністрації та місцевого самоврядування, землевласниками і землекористувачами.

Цей процес є затратним, але водночас і таким, що працює на регіон у плані привабливості для інвесторів, для розвитку територій 
тощо. Тому ми і розглядаємо нормативну грошову оцінку земель як результат і процес, що сприятимуть стимулюванню розвитку регіонів, розвитку громад.

Геоінформаційні технології забезпечують обмін інформацією між учасниками процесу на основі комп'ютерних методів фіксації вихідних даних і результатів грошової оцінки земель на етапах виконання робіт проектними організаціями, передачі результатів в органи управління земельними ресурсами та державної податкової адміністрації. Результати передаються не тільки в традиційному (паперовому) виді, а й на електронних носіях в форматах цифрових карт і баз даних [26].

Така технологія забезпечує ефективне використання результатів грошової оцінки земель для автоматизованого визначення розмірів платежів за кожну земельну ділянку з урахуванням іiі місця розташування, функціонального використання і впливу локальних факторів, а також для постійного моніторингу грошової оцінки i прогнозування надходжень до бюджету від справляння платежів за землю.

На думку фахівців, обгрунтованість оцінки земельних ділянок має важливе соціальне значення, оскільки захищатиме інтереси мільйонів громадян, які набули або набувають у власність земельні ділянки, сприятиме нормальному функціонуванню економічних механізмів.

Об'єктами оцінки земель є «територія адміністративно-територіальних одиниць чи їхній частин, території оціночних районів та зон, земельні ділянки або їхні частини чи сукупність земельних ділянок і прав на них, зокрема на земельні частки (паї), у межах території України», Ст.3, Закону України «Про оцінку земель» [28].

Погоджуємось 3 Н. Мехедою та Ш. Бакешевим, що «точність визначення вартості землі $є$ критичним елементом ефективної системи податкової оцінки. Вона робить свій внесок у правильність оцінки вартості освоєних земельних ділянок і гарантує, що кожен землевласник та землекористувач заплатить свою справедливу частину податку» [9]. Правильна і точна оцінка вартості землі забезпе- 
чує правильність прийняття рішень в галузі землекористування як у державному, так і в приватному секторі.

Важливого значення якісна грошова оцінка набуває в умовах проведення реформи щодо децентралізації при створені об'єднаних територіальних громад. Оскільки, одним із головних і стабільних джерел доходів органів місцевого самоврядування $є$ оподаткування земельних ділянок, яке має бути засноване на визначенні ринкової вартості цього майна. Крім того, таке оподаткування має стимулювати найбільш вигідне й ефективне використання і забудову земель територій. Підтримуємо думку А. Кошеля, що «земельна ділянка може бути використана як заставне майно, об'єкт оподатковування, товар, джерело капіталізації тощо, але при будь-якому ії використанні земельна ділянка повинна мати свою вартість» [6]. Необхідність вартісного орієнтиру земельної ділянки в правовому аспекті відстоює і А.Федун [2].

Враховуючи сучасний стрімкий розвиток інформаційних технологій у всьому світі привабливим і раціональним рішенням $\epsilon$ впровадження автоматизованої оцінки земель, яка має бути інтегрована із сучасною Національною кадастровою системою.

Відповідно до постанови Кабінету Міністрів України від 07.02.2018 № 105 [19] впродовж 2018 року здійснювались роботи 3 проведення загальнонаціональної (всеукраїнської) нормативної грошової оцінки земель сільськогосподарського призначення за межами населених пунктів. Всі дані про загальнонаціональну нормативну грошову оцінку земель сільськогосподарського призначення зведено в єдину систему та створено портал-дзеркало із можливістю онлайн-розрахунку нормативної грошової оцінки зареєстрованих у Державному земельному кадастрі земельних ділянок [27]. Відомості про загальнонаціональну (всеукраїнську) нормативну грошову оцінку земель сільськогосподарського призначення використовуються виключно для формування витягів 3 технічної документації про нормативну грошову оцінку земельних ділянок сільськогосподарського призначення незалежно від форми власності (крім земель сільськогосподарського призначення в межах населених пунктів) [19]. 
У сучасних умовах як елементарну одиницю природно-сільськогосподарського районування доцільно розглядати територію сільських (селищних, міських) рад, що характеризується більшменш сталими межами, на відміну від землеволодінь та землекористувань, які базуються на орендних відносинах та приватній власності на землю і не є сталими. Відповідно до створеної Схеми (карти) природно-сільськогосподарського районування земель [4] Миколаївська область розташована в межах чотирьох природносільськогосподарських зон - Лісостепу, Степу, Степової посушливої та Сухостепової що зазначено у таблиці 1.

На території області природно-сільськогосподарські зони розміщуються із півночі на південь у вищезазначеному переліку. В цьому ж напрямку наростає ксероморфність клімату, змінюються структура грунтового покриву, а також ландшафтний устрій, що зумовлює й обов'язкову диференціацію грунтозахисних та інших заходів.

Таблиця 1

Перелік природно-сільськогосподарського районування земель Миколаївської області

\begin{tabular}{|c|c|c|c|}
\hline $\begin{array}{c}\text { Природно- } \\
\text { сільсько- } \\
\text { господарський } \\
\text { район }\end{array}$ & $\begin{array}{c}\text { Природно- } \\
\text { сільського- } \\
\text { сподарський } \\
\text { Кривоозерський } \\
\text { (0202074801) }\end{array}$ & $\begin{array}{c}\text { Природно- } \\
\text { сільсько- } \\
\text { господарська } \\
\text { провінція }\end{array}$ & $\begin{array}{c}\text { Природно- } \\
\text { сільсько- } \\
\text { господарська } \\
\text { зона }\end{array}$ \\
\cline { 1 - 4 } Доманівсько- & $\begin{array}{c}\text { Бузо-Середньо- } \\
\text { дніпровський }\end{array}$ & $\begin{array}{c}\text { Лісостепова } \\
\text { Правобережна }\end{array}$ & $\begin{array}{c}\text { Зона } \\
\text { Лісостепу }\end{array}$ \\
$\begin{array}{c}\text { Арбузинський } \\
\text { (0302024802) }\end{array}$ & Інгульський & Правобережна & Зона Степу \\
\cline { 1 - 1 } Сланецько- & & & \\
Казанківський & & & \\
(0302024804) & & & \\
\hline Вознесенський & & & \\
$(0302024803)$ & & & \\
\hline
\end{tabular}


продовження таблиці 1

\begin{tabular}{|c|c|c|c|}
\hline $\begin{array}{c}\text { Природно- } \\
\text { сільсько- } \\
\text { господарський } \\
\text { район }\end{array}$ & $\begin{array}{c}\text { Природно- } \\
\text { сільського- } \\
\text { сподарський } \\
\text { округ } \\
\end{array}$ & $\begin{array}{c}\text { Природно- } \\
\text { сільсько- } \\
\text { господарська } \\
\text { провінція } \\
\end{array}$ & $\begin{array}{c}\text { Природно- } \\
\text { сільсько- } \\
\text { господарська } \\
\text { зона } \\
\end{array}$ \\
\hline $\begin{array}{c}\text { Новоодеський } \\
\text { (0402024805) }\end{array}$ & \multirow{2}{*}{$\begin{array}{c}\text { Дністровсько- } \\
\text { Нижньо- } \\
\text { дніпровський }\end{array}$} & \multirow{2}{*}{$\begin{array}{c}\text { Степова } \\
\text { посушлива } \\
\text { Правобережна }\end{array}$} & \multirow{2}{*}{$\begin{array}{c}\text { Степова } \\
\text { Посушлива } \\
\text { Зона }\end{array}$} \\
\hline $\begin{array}{l}\text { Баштансько- } \\
\text { Снігурівський } \\
\text { (0402024806) }\end{array}$ & & & \\
\hline $\begin{array}{l}\text { Очаківський } \\
\text { (0501014807) }\end{array}$ & Присиваський & $\begin{array}{l}\text { Сухостепова } \\
\text { Присиваська }\end{array}$ & $\begin{array}{c}\text { Сухостепова } \\
\text { Зона }\end{array}$ \\
\hline
\end{tabular}

Таблиця 2

Бали бонітетів грунтів (Миколаївська область)

\begin{tabular}{|c|l|llllll|l|}
\hline Назва сільсько & \multicolumn{70}{|c|}{$\begin{array}{l}\text { господарських } \\
\text { угідь }\end{array}$} & 74801 & 24802 & 24803 & 24804 & 24805 & 24806 & 14807 \\
\hline $\begin{array}{c}\text { Рілля } \\
\text { (Перелоги) }\end{array}$ & 51 & 49 & 44 & 40 & 35 & 34 & 29 \\
\hline $\begin{array}{c}\text { Багаторічні } \\
\text { насадження }\end{array}$ & 48 & 47 & 20 & 37 & 31 & 30 & 27 \\
\hline Сіножаті & 27 & 36 & 48 & 42 & 0 & 24 & 27 \\
\hline Пасовища & 37 & 36 & 34 & 29 & 24 & 26 & 22 \\
\hline
\end{tabular}

У грошовому вираженні в середньому 1 га сільськогосподарських угідь оцінюється зокрема, рілля 27,04 тис. грн, багаторічні насадження $-47,05$ тис. грн, сіножаті - 8,21 тис. грн, пасовища $-5,84$ тис. грн. Згідно з бонітетною та грошовою оцінками, найбільш ефективно в Миколаївській області культивувати зернові, кормові, овоче-баштанні культури, займатися садівництвом і виноградарством.

Поширеною є теза, що «відомості про загальнонаціональну (всеукраїнську) нормативну грошову оцінку земель сільськогосподарського призначення дозволять органам місцевого самоврядування отримати актуальну базу для визначення розміру плати за землю 
без необхідності залучення коштів місцевого бюджету або власників та землекористувачів та дозволить значно скоротити час на підготовку до продажу на земельних торгах прав оренди земельних ділянок, що забезпечить сталі надходження до місцевих бюджетів за рахунок плати за землю». І це так, наприклад, в результаті продажу прав оренди на конкурентних засадах до місцевих бюджетів за рахунок плати за землю у період 2015 - 2019 роки надйшло 34 565,32 тис. грн.

3 початку 2020 року фахівці Головного управління Держгеокадастру у Миколаївській області видали фізичним та юридичним особам 46 тис.764 витяги з технічної документації про нормативну грошову оцінку земельної ділянки [3].

Найбільше таких документів видано щодо ділянок, розташованих на територіях Миколаївського (11 166), Вітовського (6 409), Баштанського (5 863), Березанського (2 765), Новоодеського (2 613) та Новобузького (2 458) районів Миколаївської області. Із загальної кількості документів 39621 витягів надано на підставі заяв, сформованих через Публічну кадастрову карту в режимі онлайн, а через Центри надання адміністративних послуг надано 7 143 витяги [3].

Відповідно до вимог статей 13, 18 Закону України «Про оцінку земель» [28] та з урахуванням норми пункту 271.2 статті 271 Податкового кодексу України [16], а також згідно з даними Довідника показників нормативної грошової оцінки земель населених пунктів на 2019-2020 оціночний рік нормативна грошова оцінка земель потребувала актуалізації. На Миколаївщині потребували оновлення нормативної грошової оцінки 864 населених пункти [3].

3 метою оновлення нормативної грошової оцінки земель населених пунктів та внесення відповідних відомостей до Державного земельного кадастру територіальними відділами Головного управління Держгеокадастру Миколаївської області [10] триває робота 3 представниками місцевого самоврядування, шляхом надання органам місцевого самоврядування організаційно-методичної допомоги 3 питань організації проведення робіт з нормативної грошової оцінки земель населених пунктів Миколаївської області. 
На прикладі технічної документації з нормативної грошової оцінки селища Святомиколаївка Вітовського району Миколаївської області спробуємо показати переваги виконання робіт 3 нормативної грошової оцінки земель з різних аспектів, розширити уявлення про регуляторний та стимулюючий характер нормативно-грошової оцінки, про iї практичне значення, про важливість актуалізації нормативно-грошової оціник.

Технічну документацію 3 нормативної грошової оцінки земель селища Святомиколаївки Вітовського району Миколаївської області було виконано згідно договору №48-2020-0004-НГО від 16.06.2020 р., укладеного між Мішково-Погорілівською сільською радою та ТОВ «ІНЖЕНЕРНО-КОНСАЛТИНГОВА ГРУПА «АЛЬФА» на підставі рішення II позачергової сесії 8 скликання Мішково-Погорілівської сільської ради від 05 березня 2020 року за №4 (стаття 15 Закону України «Про оцінку земель») [28].

Нормативна грошова оцінка земель селища Святомиколаївка розроблялась на територію, що відповідає існуючій межі села. Площа земель селища відповідно до статистичних даних станом на 01.01.2020 р. складає 157, 1000 га. При виконанні грошової оцінки земель села використовувалась інформація надана сільською радою, окремими підприємствами та установами, а також проектна документація.

Селище Святомиколаївка розташоване у центральній частині Миколаївської області, у степовій зоні. За фізико-географічним районуванням територія знаходиться у межах Причорноморської низовини. Клімат території атлантико-континентальний, обумовлений іiі розташуванням в степовій зоні, що характеризується тривалим жарким літом, малосніжною короткою теплою та м'якою зимою, недостатнім зволоженням та тривалими періодами з частими відлигами $\mathrm{i}$ нестійким сніговим покровом. В липні та серпні переважає сонячна, жарка і суха погода.

У гідрогеологічному відношенні даний регіон розташований у південній частині північного крила Причорноморського артезіанського басейну. Підземні води зустрічаються в породах майже всіх стратиграфічних підрозділів. Забезпеченість потреби у воді 
по району за рахунок існуючих запасів підземних вод питної якості (з мінералізацією до 1,5 г/дм) становить близько 20\%. Підземні води в Вітовському районі використовуються інтенсивно, сучасний водовідбір по яких перевищує прогнозні ресурси підземних вод в 1,15 рази у 2011 р. Слід зазначити також, що значна частина вод за вмістом солей не відповідає якості питних. Аналіз існуючого водовідбору по району свідчить про те, що величина прогнозних ресурсів підземних вод в районі не відповідає рівню сучасного водоспоживання, тобто потрібна переоцінка запасів.

Рельєф території населеного пункту спокійний зі схилами $1-5^{0}$, грунти придатні до будівництва. Небезпечні геологічні процеси на території села відсутні. Значні промислові підприємства, які є забруднювачами повітря на території села відсутні. Недопустиме напруження електромагнітного поля на території відсутнє.

В межах території, що оцінюється, система поверхневих водотоків відсутня. Згідно з гідрологічним районуванням, територія відноситься до Причорноморської області надзвичайно низької водності. Основну роль в живленні населеного пункту відіграють атмосферні опади. Гідрологічний режим визначається трьома основними чинниками: опадами, стоком схилу (материковим) i випаровуванням.

Геологічна будова, особливості рельєфу і клімату визначили різноманітність грунтового покриву території, що оцінюється. Територія селища Святомиколаївка віднесена до 06-БаштанськоСнігурівського природно-сільськогосподарського району. Грунтовий покрив селища Святомиколаївка: лучно-болотні слабосолончакові важкосуглинкові грунти на алювіально-делювіальних відкладах (143e), дернові слаборозвинені супіщані грунти на пісках (175в), дернові розвинені супіщані грунти на пісках (176в), розмиті грунти та виходи рихлих порід (215a).

Територія розташована в зоні посушливого кліматичного району, тому агротехнічні заходи повинні бути спрямовані на затримання і збереження вологи в грунті. Дані грунти відносяться до середньо-родючих. Вони є придатними для вирощування усіх видів деревних і чагарникових насаджень, характерних для степової 
зони. В умовах степової зони грунти потребують штучного поливу. У межах Вітовського адміністративного району мінеральнобудівельна база корисних копалин що мають промислове значення, практично відсутня.

Селище Святомиколаївка почало формуватися в 70-х роках $\mathrm{XX}$ ст., а як окремий населений пункт існує 3 90-х років XX ст. Селище Святомиколаївка (в минулому селище Пам'яті Комунарів) входить до адміністративно-територіального устрою МішковоПогорілівської сільської ради (у підпорядкуванні) з адміністративнотериторіальним центром - с. Мішково-Погорілове. Селище знаходиться на північному-сході за 15 км від районного центру та за 8,5-9 км від обласного центру - міста Миколаєва на закруті ріки Інгул. Відстань до залізничної станції - 5 км. Територія селища входить в приміську зону міста Миколаєва (базовим господарством був радгосп «Пам’ять Комунарів», який згідно Рішення виконкому Миколаївської обласної ради народних депутатів від 03.01.1992 року за №8 увійшов до приміської зони міста Миколаєва) та в агломерацію Миколаїв-Воскресенськ, не входить в жодну із зон радіоактивного забруднення внаслідок Чорнобильської катастрофи; населений пункт не має статусу курорту. Кількість населення станом на 01.01.2020 р. - 830 чол. Мішково-Погорілівська сільська рада межує з містом Миколаїв, Коларівською, Воскресенською та Полігонівською сільськими радами Вітовського району Миколаївської області.

Селище повністю електрифіковане, має централізовану систему газопостачання, частково телефонізоване, має інтернетмережу. Водопостачання селища Святомиколаївка здійснюється 3 артезіанських свердловин (3 свердловини), через водопровідну мережу прокладену по вулицях; централізована каналізація відсутня.

Зовнішні зв'язки с-ща Святомиколаївка 3 населеними пунктами Миколаївського та інших регіонів України здійснюється автомобільним та автобусним транспортом (налаштовано обслуговування громадян автобусами та маршрутними таксі). Вулично-дорожня мережа частково має частково тверде асфальтобетонне покриття. 
Забудовані землі представлено землями житлової, громадської, комунальної забудови, ділянками, відведеними під житлове будівництво, зеленими насадженнями загального користування, вулично-дорожньою мережею та іншими забудованими землями.

Історично сформована планувальна структура селища Святомиколаївка визначається мережею житлових вулиць та системою поперечних провулків. Забудова села представлена кварталами садибної забудови i представляє собою регулярну планувальну структуру. Житловий фонд селища - одно-, двохта трьохповерховий, індивідуальний (переважно садибного типу (домогосподарства)). Житловий фонд станом на 01.01.2020 p. становив 22,8 тис.м2 загальної площі. Житлова забудова складається 3287 індивідуальних будинків 3 присадибними ділянками та 222 земельні ділянки, що незабудовані. В північній частині села сформувався громадський центр села: дитячий садок, фельдшерсько-акушерський пункт, магазин та парк 3 дитячим ігровим майданчиком. Виробничі складські приміщення для обслуговування цеху з переробки деревини ТОВ «НІКА + 7» разом з господарським двором розташовані у західній частині селища.

Система обслуговування включає установи освіти (дошкільнийо навчальний заклад №2 «Чебурашка» на 40 місць), охорони здоров’я (фельдшерсько-акушерський пункт (7 ліжок), підприємства та торгівлі. Установи обслуговування розміщаються в основному в будинках, які придатні для подальшого використання. Порівняння досягнутого рівня обслуговування 3 нормативними показниками свідчить про те, що мережа установ обслуговування розвинена недостатньо і не задовольняє потреби населення в необхідних послугах. Недостатня кількість установ культури, підприємств побутового обслуговування, практично відсутні відкриті спортивні площинні споруди. Господарський комплекс території представлено сільським господарством: землеробством, рослинництвом транспортом та зв'язком, сферою послуг.

Незабудовані землі включають землі, вкриті лісовою рослинністю, сільськогосподарські угіддя, відкриті землі без рослинного покриву. 
Зелені насадження загального користування складають 9,8528 га.; вулиці, набережні, площі складають 24,0687 га.

Нормативній грошовій оцінці підлягають землі всіх категорій за основним цільовим призначенням, які розташовуються в адміністративних межах селища Святомиколаївка. Забудовані землі, землі лісового та водного фонду (ділянки водного фонду, що розташовані в межах населених пунктів, які використовуються для риборозведення, здійснюється згідно з Порядком нормативної грошової оцінки земель несільськогосподарського призначення (крім земель населених пунктів) [12], а також усі інші землі у встановлених межах населеного пункту (окрім земель сільськогосподарського використання) оцінюються по єдиній методиці. Землі сільськогосподарського використання оцінюються за агровиробничими якостями грунтів.

Грошова оцінка земель населених пунктів є капіталізованим рентним доходом із земельної ділянки. В населених пунктах рентний дохід виникає, перш за все, завдяки зручності місцерозташування земельної ділянки та рівню їі інфраструктурного облаштування.

Інформаційною базою для визначення витрат на освоєння та облаштування території селища Святомиколаївка стали дані статистичної звітності про натуральні та вартісні показники, надані Мішково-Погорілівською сільською радою та комунальними службами.

Отже, технічну документацію 3 нормативної грошової оцінки земель селища Святомиколаївка виконано у відповідності 3 вимогами Державного стандарту СОУ ДКЗР 00032632- 012:2009 «Оцінка земель. Правила розроблення технічної документації 3 нормативної грошової оцінки земель населених пунктів» [25]. Пояснювальна записка містить текстову частину та табличний матеріал зведений, переважно, у додатки. Графічний матеріал включає: «Схему економіко-планувального зонування території села» (М 1:5000), «Схеми прояву локальних факторів оцінки» (М 1:5000), а також «Картограму розповсюдження агровиробничих груп грунтів», (М 1:5000). Схеми виконано 3 використанням геоінформаційних технологій за допомогою програмного забезпечення «НОРМАТИВ+». 
Таким чином, аналіз засвідчив, що у переважній більшості наданих показників окремих елементів інженерно-транспортної та природоохоронної інфраструктури села наведена не повна відновна, а балансова вартість, тобто, без урахування індексації основних фондів, яка здійснювалась за останні роки. В зв’язку з цим для розрахунку повної відновної вартості елементів інфраструктури використовувались натуральні показники.

Загальна вартість витрат на освоєння та облаштування території селища Святомиколаївка на 01.01.2020 року становить 70927 313.65 грн., 3 яких основна частка припадає на таку групу показників як вулично-дорожня мережа $(65,0980 \%)$.

Базою для обчислення витрат на освоєння та облаштування в розрахунку на $1 \mathrm{~m}^{2} \epsilon$ оціночна територія, яка дорівнює площі забудованої території селища Святомиколаївка у встановлених межах. Розрахунок площі здійснювався на основі форми 6-Зем на 01.01.2020 року.

Таким чином, витрати на освоєння та облаштування території селища Святомиколаївка складають:

70927313.65 грн : $1280342.00 \mathrm{~m}^{2}=55.40 г р н / \mathrm{M}^{2}$.

Згідно «Порядку нормативної грошової оцінки земель населених пунктів» [11], значення коефіцієнту Км1 є добутком коефіцієнтів, які враховують:

- чисельність населення, географічне положення, адміністративний статус населеного пункту та його господарські функції (додаток 2, пункт 7 розділу II);

- входження в приміську зону міст з чисельністю населення 250,0-499,9 тис. осіб (додаток 3 , пункт 7 розділу II);

- $\quad$ наявність у населеного пункту статусу курорту (додаток 4, пункт 7 розділу II);

- входження до зон радіаційного забруднення (додаток 5, пункт 7 розділу II).

Оскільки селище Святомиколаївка входить в приміську зону міста Миколаєва (рішення виконкому Миколаївської обласної ради народних депутатів від 03.01.1992 року за №8 увійшов до приміської зони міста Миколаєва), чисельність населення якого становить 
майже 500 тис. чол. - для території селища Святомиколаївка Км1 = 1,2 .

Таким чином, середня (базова вартість) $1 \mathrm{~m}^{2}$ земель селища Святомиколаївка, обчислена відповідно до «Порядку нормативної грошової оцінки земель сільськогосподарського призначення та населених пунктів» [13], становить:

$$
\text { Цнм = } \begin{gathered}
55.40 \mathrm{rpH} / \mathrm{M}^{2} \times 6 \\
3
\end{gathered}
$$

Коефіцієнт місцерозташування окремої земельної ділянки Км відображає іiї відносну цінність (вартість) в межах території населеного пункту. Даний коефіцієнт є добутком трьох коефіцієнтів Км1, Км2 та Км3, які характеризують залежність рентного доходу від регіональних, зональних та локальних особливостей розташування земельної ділянки. Оскільки коефіцієнт Км1 доцільно враховувати на стадії визначення базової вартості земель населеного пункту, у подальшому при визначенні коефіцієнту місцерозташування земельної ділянки ми матимемо справу лише з коефіцієнтами Км2 та Км3.

Процес рентоутворення в межах населеного пункту відбувається, як правило, на достатньо великій та внутрішньо неоднорідній території, яка характеризується складним поєднанням природних i антропогенних ландшафтів, різницею в функціонально-планувальних якостях, різним рівнем прибутковості від використання земель, що призводить до неоднорідності прояву рентоутворюючих факторів. Це обумовлює необхідність ії землеоціночної структуризації - економіко-планувального зонування території.

Після аналізу функціонально-планувальної структури селища Святомиколаївка було виділено 7 оціночних районів.

В результаті проведення економіко-планувального зонування селища Святомиколаївка було виділено 2 зони (межі зон вказано на Схемі економіко-планувального зонування) див. табл. 3 та 4. 


\section{Визначення зонального коефіціснта Км2 та грошова оцінка кв.м землі в межах економіко-планувальних зон}

\begin{tabular}{|c|c|c|c|c|c|}
\hline $\begin{array}{c}\text { Економіко- } \\
\text { планувальні зони }\end{array}$ & $\begin{array}{c}\text { Землеоціночні } \\
\text { райони }\end{array}$ & $\mathrm{I}_{\mathrm{i}}$ & Км2 & $\begin{array}{c}\text { Середня } \\
\text { (базова) } \\
\text { вартість, грн } \\
\end{array}$ & $\begin{array}{c}\text { Грошова } \\
\text { оцінка } 1 \text { м2 } \\
\text { земель, грн } \\
\end{array}$ \\
\hline \multirow{5}{*}{ I } & 1 & 1.25 & 1.17 & \multirow{9}{*}{132.96} & \multirow{5}{*}{155.56} \\
\hline & 2 & 1.29 & 1.17 & & \\
\hline & 3 & 0.96 & 1.17 & & \\
\hline & 4 & 0.87 & 1.17 & & \\
\hline & 5 & 1.4 & 1.17 & & \\
\hline \multirow{2}{*}{ I I } & 6 & 0.55 & 0.75 & & \multirow{2}{*}{99.72} \\
\hline & 7 & 0.69 & 0.75 & & \\
\hline \multicolumn{2}{|c|}{ Максимальне значення по стовпцю } & 1.4 & 1.17 & & 155.56 \\
\hline \multicolumn{2}{|c|}{ Мінімальне значення по стовпцю } & 0.55 & 0.75 & & 99.72 \\
\hline
\end{tabular}

Таблиця 4

\section{Опис меж економіко-планувальних зон}

\begin{tabular}{|c|c|}
\hline $\begin{array}{c}\text { № } \\
\text { зони }\end{array}$ & \multicolumn{1}{|c|}{ Опис меж } \\
\hline \multirow{2}{*}{ I } & $\begin{array}{l}\text { Межа села Мішково-Погорілове (берег річки Інгул) - Зовнішня } \\
\text { межа селища Святомиколаївка (вул. Рівненська) - Зовнішня } \\
\text { селища Селища Святомиколаївка (лісосмуга) - Зовнішня межа } \\
\text { II зони та межа оціночного району 6 (поле) - Зовнішня межа } \\
\text { селища Святомиколаївка (берег річки Інгул) }\end{array}$ \\
\hline II & $\begin{array}{l}\text { Мовнішня межа селища Святомиколаївка (лісосмуга) - Зовнішня } \\
\text { межа селища Святомиколаївка (вул. Живописна) - Зовнішня } \\
\text { межа селища Святомиколаївка (грунтова дорога) - Зовнішня } \\
\text { суміжної І зони та межа оціночного району 5 (грунтова дорога) }\end{array}$ \\
\hline \hline
\end{tabular}


Встановлення переліку локальних факторів та обгрунтування їх значень здійснюється на базі містобудівної документації та результатів спеціальних досліджень.

При встановленні значення локального коефіцієнта для окремої земельної ділянки необхідно обгрунтовувати його значення на основі визначення частки площі, яку займає цей фактор на земельній ділянці. Установлення частки площі здійснюється з використанням автоматизованої системи, наприклад програмного забезпечення «НОРМАТИВ+».

Отже, аналіз, проведений в процесі виконання грошової оцінки селища Святомиколаївка, виявив 6 локальних факторів, (табл. 5) які можуть вплинути на загальне значення коефіцієнту Км3. Для обчислення Км3 враховуються перераховані нижче локальні фактори. При цьому добуток пофакторних оцінок не повинен бути нижче 0,50 і вище 1,50, а саме:

Таблиця 5

\section{Перелік локальних факторів}

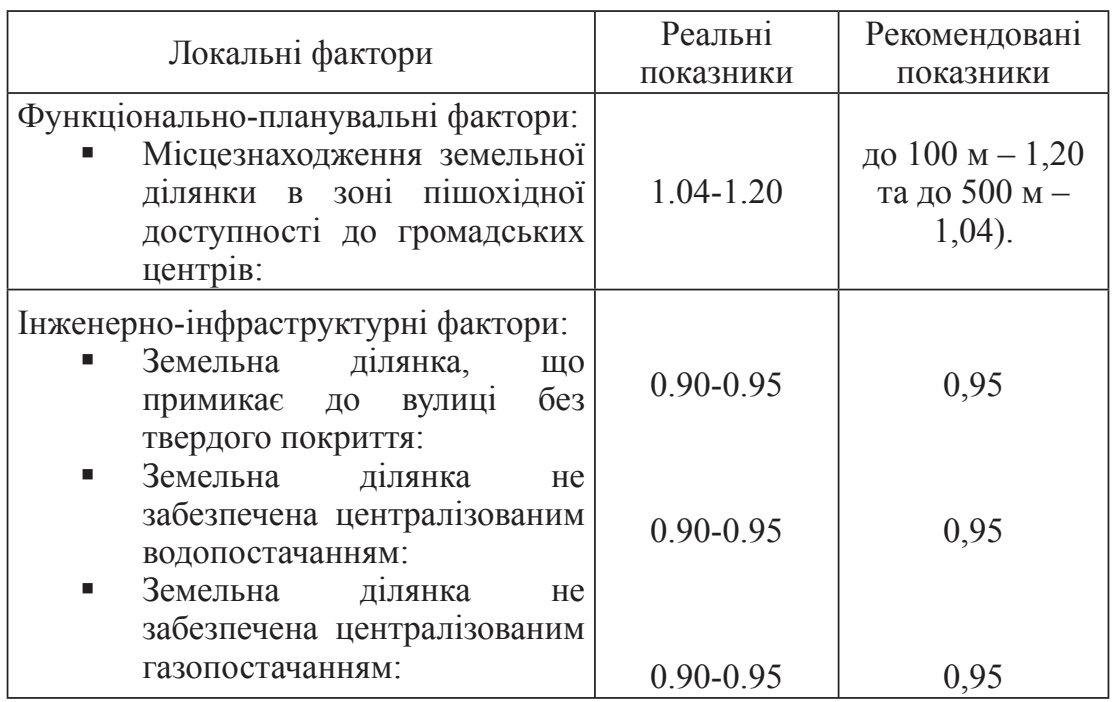


продовження таблиці 5

Санітарно-гігієнічні фактори

- Місцезнаходження земельної ділянки у санітарно-захисній зоні:

- Місцезнаходження земельної ділянки у водоохоронній зоні:

\begin{tabular}{|c|c|}
\hline $0.80-0.96$ & 0,96 \\
$1.02-1.05$ & 1,05 \\
\hline
\end{tabular}

У відповідності 3 «Порядком грошової оцінки земель сільськогосподарського призначення» [13] землі сільськогосподарського використання оцінюються за величиною диференційного рентного прибутку, який створюється при виробництві зернових культур і визначається за даними економічної оцінки земель, тобто з урахуванням конкретного грунтового покриву. Проте, оскільки на землях населених пунктів грунтові обстеження, як правило, не проводились, на такі землі картографічна інформація про грунтовий покрив (карти грунтів, експлікація агровиробничих грунтів) практично відсутня. Здійснити грунтові зйомки за вкрай обмежений термін на виконання землеоціночних робіт, враховуючи велику кількість населених пунктів і великі площі необстежених земель неможливо.

Розв'язання проблеми полягає лише у визначенні основних агровиробничих груп грунтів в межах населеного пункту за допомогою допоміжних матеріалів - топокарти місцевості та карти агровиробничих груп грунтів прилеглих до населеного пункту територій. В такий спосіб була складена «Картограма розповсюдження агровиробничих груп грунті» (М 1: 5000), а також визначено відповідні агровиробничі групи грунтів.

Згідно довідки про якісний стан грунтового покриву земельних ділянок селища Святомиколаївка Вітовського району Миколаївської області наданої ДП «Миколаївським науково-дослідним та проектним інститутом землеустрою» від 19.06.2020 р. за вих. №01-13/245 та відповідно до даних загальнонаціональної (всеукраїнської) нормативної грошової оцінки земель сільськогосподарського призначення було визначено основні агровиробничі групи грунтів в межах села (шифри грунтів наведено у відповідності з їх загальнодержавним номенклатурним списком наведено у таблиці 3): 
Таблиця 6

Перелік шифрів грунтів відповідно до загальнодержавного номенклатурного списку

\begin{tabular}{|c|l|}
\hline $\begin{array}{c}\text { Шифр } \\
\text { агрогрупи }\end{array}$ & \multicolumn{1}{c|}{ Тип грунту } \\
\hline $143 \mathrm{e}$ & $\begin{array}{l}\text { Лучно - болотні слабосолончакові важкосуглинкові грунти } \\
\text { на алювіально-делювіальних відкладах }\end{array}$ \\
\hline 175 в & Лучно-болотні слабосолончакові важкосуглинкові грунти \\
\hline $176 в$ & дернові слаборозвинені супіщані грунти на пісках \\
\hline $215 \mathrm{a}$ & Розмиті грунти та виходи рихлих порід \\
\hline
\end{tabular}

Оцінку виконано для всіх категорій земель сільськогосподарського використання, що знаходяться в межах селища Святомиколаївка. Таксономічними одиницями при виконанні оцінки $є$ агровиробничі групи грунтів, перелік яких щодо території населеного пункту наведено вище.

Грошова оцінка 1 га земель агровиробничих груп грунтів (Гагр) розрахована за формулою:

\section{Гагр $=$ Гу $\times$ Багр : Б}

У відповідності із природно-сільськогосподарським районуванням України, селище Святомиколаївка знаходиться в межах Баштансько-Снігурівського (ПС-6) природно-сільськогосподарського району Миколаївської області.

Норматив капіталізованого рентного доходу 1 га земель по природно-сільськогосподарському району, станом на 01.01.2020 року (3 урахуванням індексації згідно Постанови Кабінету Міністрів України від 12 травня 2000 року №785) становить:

$$
\begin{aligned}
& \text { ріллі - } 23016.54 \text { грн., } \\
& \text { багаторічних насаджень - 41349,75 грн., } \\
& \text { сіножатей - } 5797.62 \text { грн.; } \\
& \text { пасовищ - 5063.75 грн.; } \\
& \text { несільськогосподарських угідь - 24599.46 грн. }
\end{aligned}
$$


Згідно довідки про якісний стан грунтового покриву земельних ділянок селища Святомиколаївка Вітовського району Миколаївської області наданої ДП «Миколаївським науково-дослідним та проектним інститутом землеустрою» від 16.06.2020 р. за вих. №01-13/245 та відповідно до даних загальнонаціональної (всеукраїнської) нормативної грошової оцінки земель сільськогосподарського призначення середньозважені бали бонітетів сільськогосподарських угідь (табл. 7) по 06 - Баштансько - Снігурівському природно - сільськогосподарському району становлять:

Таблиця 7

\section{Середньозважений бал бонітетів сільськогосподарських угідь}

\begin{tabular}{|l|c|}
\hline \multicolumn{1}{|c|}{ Категорія угідь } & Середньозважений бал бонітету \\
\hline Рілля & 34 \\
\hline Багаторічні насадження & 30 \\
\hline Сіножаті & 24 \\
\hline Пасовища & 26 \\
\hline
\end{tabular}

Бонітети агрогруп грунтів, виділених в межах селища Святомиколаївка для земель сільськогосподарського використання розташовані у таблиці 8, мають наступні значення:

Таблиця 8

Перелік бонітетів агрогруп грунтів

\begin{tabular}{|c|c|c|c|c|}
\hline \multirow{2}{*}{$\begin{array}{c}\text { Шифр } \\
\text { агрогрупи }\end{array}$} & \multicolumn{4}{|c|}{ Бали бонітету } \\
\cline { 2 - 5 } & Ріля & Сіножаті & $\begin{array}{c}\text { Багаторічні } \\
\text { насадження }\end{array}$ & Пасовища \\
\hline $143 \mathrm{e}$ & 5 & ---- & 4 & 4 \\
\hline $175 \mathrm{~B}$ & 10 & ---- & 5 & 11 \\
\hline $176 \mathrm{~B}$ & 14 & ---- & 10 & 15 \\
\hline $215 \mathrm{a}$ & 2 & ---- & 2 & 7 \\
\hline
\end{tabular}

Отже, грошова оцінка 1 га земель сільськогосподарського використання в межах села по агровиробничих групах грунтів станом на 01.01.2020 р. згідно табл.9 становить: 
Таблиця 9

\section{Грошова оцінка 1 га земель сільськогосподарського використання селища Святомиколаївка}

\begin{tabular}{|c|c|c|c|c|}
\hline $\begin{array}{c}\text { Шифр } \\
\text { агрогрупи }\end{array}$ & Рілля & Сіножаті & $\begin{array}{c}\text { Багаторічні } \\
\text { насадження }\end{array}$ & Пасовища \\
\hline $143 \mathrm{e}$ & 3384,79 & ---- & 5513,30 & 779.04 \\
\hline $175 \mathrm{в}$ & 6769,57 & ----- & 6891,62 & 2142.36 \\
\hline $176 \mathrm{~B}$ & 9477,40 & ---- & 13783,25 & 2921.39 \\
\hline $215 \mathrm{a}$ & 1353,91 & ----- & 2756.65 & 1363.32 \\
\hline
\end{tabular}

Визначення грошової оцінки будь-якої ділянки земель сільськогосподарського використання в межах населених пунктів здійснюється шляхом сумування добутків грошової оцінки кожної агрогруп грунтів, що входять до складу даної ділянки. Ідентифікація агровиробничих груп грунтів здійснюється на основі використання Картограми розповсюдження агровиробничих груп грунтів, яка передається замовнику у складі матеріалів грошової оцінки земель селища.

Згідно п.10 Порядку нормативної грошової оцінки земель населених пунктів [11] вартість одного квадратного метра земельної ділянки певного функціонального використання визначається 3 урахуванням територіально-планувальних, інженерно-геологічних, історико-культурних, природно-ландшафтних, санітарно-гігієнічних та інженерно-інфраструктурних особливостей місця ії розташування в межах економіко-планувальної зони за формулою:

$$
\text { Цн }=\text { Цнз } \times \text { К } \phi \times \mathrm{KM} 3
$$

Коефіцієнт функціонального використання для земельних ділянок змішаного використання визначається як середньозважене (за площею) значення коефіцієнтів функціонального використання окремих частин земельної ділянки змішаного використання показано 
у таблиці 10. Підставою для виділення частин земельної ділянки різного функціонального використання є виключно затверджені дані інвентаризації земельної ділянки та землеустрою. Грошова оцінка земель різного функціонального призначення у розрізі економікопланувальних зон (грн. за 1 кв.м) селища виглядає так:

- $\quad$ Землі промисловості - 1,2

- Землі комерційного використання $-2,5$

- $\quad$ Землі громадського призначення - 0,7

- $\quad$ Землі змішаного використання - 1

- $\quad$ Землі транспорту - 1

- Землі зв'язку - 1,2

- Землі технічної інфраструктури - 0,65

- Землі рекреаційного призначення та інші відкриті землі - 0,5

- Землі житлової забудови - 1

- $\quad$ Інші відкриті (незабудовані) землі - 0,1

- Землі під виробничими дворами і будівлями КСП - 1

- $\quad$ Землі під гідротехнічними спорудами - 0,65

- $\quad$ Землі зелених насаджень - 0,5

- Землі кладовищ та крематоріїв - 0,5

- $\quad$ Землі запасу та резервного фонду - 0,5

Таблиця 10

Коефіцієнт функціонального розрахунку для земельних ділянок змішаного використання

\begin{tabular}{|c|c|c|c|c|c|c|c|c|c|}
\hline $\begin{array}{c}\text { № } \\
\text { зони }\end{array}$ & $\begin{array}{c}\text { Кф= } \\
2.5\end{array}$ & $\begin{array}{c}\text { Кф } \\
2\end{array}$ & $\begin{array}{c}\text { Кф= } \\
1.5\end{array}$ & $\begin{array}{c}\text { Кф= } \\
1.2\end{array}$ & $\begin{array}{c}\text { Кф }= \\
1\end{array}$ & $\begin{array}{c}\text { Кф= } \\
0.7\end{array}$ & $\begin{array}{c}\text { Кф= } \\
0.65\end{array}$ & $\begin{array}{c}\text { Кф= } \\
0.5\end{array}$ & $\begin{array}{c}\text { Кф= } \\
0.1\end{array}$ \\
\hline I & 388.91 & 311.13 & 233.34 & 186.68 & 155.56 & 108.89 & 101.12 & 77.78 & 15.56 \\
\hline II & 249.30 & 199.44 & 149.58 & 119.66 & 99.72 & 69.80 & 64.82 & 49.86 & 9.97 \\
\hline
\end{tabular}

Отже, технічну документацію з нормативної грошової оцінки селища Святомиколаївка Вітовського району Миколаївської області розроблено ТОВ «Інженерно-консалтинговою групою «Альфа» у віповідності із договором від 16.06.2020 року № 48-2020-0004- 
НГО укладеного з Мішково-Погорілівською сільською радою та на підставі рішення II позачергової сесії 8 скликання Мішково-Погорілівської сільської ради від 05.03.2020 № 7.

Представлені на експертизу матеріали 3 нормативно грошової оцінки земель населеного пункту розроблено на основі існуючої законодавчої та нормативно-методичної бази проведення робіт 3 грошової оцінки земель сільськогосподарського призначення та населених пунктів (Висновок державної експертизи землевпорядної документації від 07.07.2020 № 2019-20).

Технічна докуменація в повній мірі відповідає вимогам чинного законодавства України, встановленим нормам і правилам і була затверджена рішенням V сесії 8 скликання Мішково-Погорілівською сільською радою Вітовського району Миколаївської області від 13.07.2020 № 17 та вступить в дію з 01.01.2021 року.

Отже, відповідно до Закону України «Про землеустрій» своєчасне оновлення нормативної грошової оцінки земель населених пунктів є одним з важливих завдань для забезпечення дохідної частини бюджетів сільських, селищних рад. Тому керівникам сільських, селищних рад необхідно вживати вичерпних заходів щодо забезпечення періодичності проведення нормативної грошової оцінки земель у встановленому законодавством порядку, здійснювати актуалізацію нормативно грошової оцінки.

Висновки. Підсумовуючи викладений матеріал доцільно зазначити, що порівняно 3 Технічною документацією 3 нормативної грошової оцінки селища Святомиколаївка Вітовського району Миколаївської області, яку було затверджено від 18.11.2011 року №14, середня (базова) вартість 1 кв.м земель селища Святомиколаївка зросла з 62,30 грн. до 132,96 грн. Завдяки розробленій та затвердженій новій технічній документації 3 нормативної грошової оцінки селища зміниться і наповнення місцевого бюджету.

3 метою активізації оціночної діяльності та актуалізації нормативної грошової оцінки земель різного призначення варто:

Посилити роз'яснювальну роботу серед учасників земельного ринку щодо необхідності та доцільності нормативної грошової оцінки 3 метою прискорення реформ, у тому числі стимулювання 
економічного розвитку регіонів України, соціально-економічного розвитку громад.

Оперативно та зрозуміло висвітлювати діяльність органів державної влади та органів місцевого самоврядування щодо земельної політики, діяльність Держгеокадастру та інших структур, пов'язаних з земельними відносинами, у тому числі з оцінкою землі, серед населення 3 метою їх залучення до реформування ринку землі з точки зору отримувачів послуг.

Активно впроваджувати геоінформаційні системи та наповнювати їх актуальною інформацію з наданням доступу, полегшенням пошуку та отриманням необхідної технічної документації з нормативної грошової оцінки земельних ділянок.

Стаття надійшла до редакції: 21.11.20

\section{NORMATIVE MONETARY VALUATION OF LAND AS A MECHANISM FOR STIMULATING COMMUNITY DEVELOPMENT}

Natalia Malynovska, $\mathrm{PhD}$ in Historical Sciences, Associate Professor at the Department of Social Work, Management and Pedagogy, Institute of Public Administration, Black Sea National University of Petro Mohyla, Mykolaiv, Ukraine.

Oleksandr Shtyrov, $\mathrm{PhD}$ in Public Administration, Associate Professor, Institute of Public Administration, Petro Mohyla Black Sea National University, Mykolaiv, Ukraine.

Nataliia Holovashchenko, Deputy Head of the Market and Land Valuation Department, Mykolaiv, Ukraine.

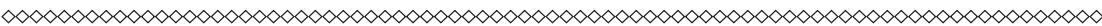

The article considers the normative monetary valuation of land as one of the mechanisms to stimulate the development of communities in the conditions of decentralization, in the conditions of formation of the land market. 
Emphasis is placed on the importance of conducting land valuation work, as it is an economic mechanism of land relations, land privatization, land mortgage lending, taxation and the formation of the land market as a whole. It is noted that the problem of the situation is that all subjects of land relations agree that land has its price, but there are differences in methodological approaches to NGOs, and therefore in practical implementation. Attention is drawn to the fact that the productive properties of land are determined by its geographical location, and therefore, due to this, in conditions of reasonable use should contribute to the socio-economic development of society.

The essence, content and spheres of application of normative monetary valuation of the land plot are analyzed, regulatory and stimulating character of normative monetary valuation of lands at the community level is traced, information on convincing value of NPO for a society on an example of the settlement Of the Nikolaev area on NGOs.

Attention is drawn to the socio-economic importance of NGOs, as the validity of land valuation is to protect the interests of millions of citizens who have acquired or are acquiring land.

On the example of technical documentation on normative monetary assessment of the settlement Svyatomikolayivka of the Vitovsky region of the Nikolaev area the advantages of performance of works on normative monetary assessment of the earths on various aspects are shown, the idea of regulatory and stimulating character of $N G O$, its practical value, importance of actualization of $N G O s$ is expanded.

In conclusion, it is stated that in order to intensify valuation activities and update the regulatory monetary valuation of land for various purposes should: strengthen advocacy among land market participants on the need and feasibility of regulatory monetary valuation to accelerate reforms, including stimulating economic development of regions of Ukraine economic development of communities; promptly and clearly cover the activities of public authorities and local governments on land policy.

Key words: normative monetary valuation of lands, actualization of normative monetary valuation, technical documentation on normative 
monetary valuation of lands, Svyatomikolayivka village of Vitovsky district of Mykolayiv region, stimulation of community development, Main Department of the State Geocadastre in Mykolayiv region, local governments.

\section{Received: 21.11.20}

\section{References}

1.

2. Drapikovskyi, O. \& Ivanova, I. (2009). Masova otsinka miskykh zemel: Ukraina ta svitovyi dosvid [Mass assessment of urban lands: Ukraine and world experience]. Visnyk Prydniprovskoi derzhavnoi akademii budivnytstva ta arkhitektury - Bulletin of the Dnieper State Academy of Civil Engineering and Architecture, 6-7, (pp. 36-42) [in Ukrainian].

3. Fedun, A.D. (2015). Pravovi aspekty zdiisnennia normatyvnoi hroshovoi otsinky zemelnykh dilianok v Ukraini [Legal aspects of the implementation of the normative monetary valuation of land in Ukraine]. Pravo $i$ suspilstvo Law and Society, 4(2), (pp. 98-104). Retrieved from http://nbuv.gov.ua/UJRN/ Pis_2015_4(2)__19 [in Ukrainian].

4. Informatsiia Holovnoho upravlinnia Derzhheokadastru u Mykolaivskii oblasti [Information of the Main Department of the State Geocadastre in the Nikolaev area]. mykolaivska.land.gov.ua. Retrieved from https://mykolaivska. land.gov.ua/na-mykolaivshchyni-potrebuiut-onovlennia-normatyvnoi-hroshovoi-otsinky-864-naselenykh-punkty [in Ukrainian].

5. Karta Mykolaivskoi oblasti [Map of the Nikolaev area]. ngo.land.gov. ua. Retrieved from https://ngo.land.gov.ua/uk/oblast/mikolayivska [in Ukrainian].

6. Kodeks Ukrainy pro nadra. Lisovyi kodeks Ukrainy. Povitrianyi kodeks Ukrainy [Subsoil Code of Ukraine. Forest Code of Ukraine. Air Code of Ukraine]. (2020, March 2). Kharkiv: Pravo [in Ukrainian].

7. Koshel, A.O. (2018). Perspektyvni napriamy udoskonalennia hroshovoi otsinky zemel $\mathrm{z}$ vykorystanniam masovykh metodiv otsiniuvannia [Perspective directions of improvement of monetary valuation of lands with the use of mass valuation methods]. Hroshova otsinka zemel v Ukraini: zdobutky, problemy, perspektyvy - Money valuation of lands in Ukraine: achievements, 
problems, prospects: Coll. Proceedings of the International Scientific and Practical Conference, (pp. 18-20). Kyiv, DP «Komprynt» [in Ukrainian].

8. Mamonov, K.A. \& Achkasov, A.Ye. \& Anopriienko, T.V. (2014). Osoblyvosti zdiisnennia normatyvnoi hroshovoi otsinky zemli na osnovi prostorovoho analizu [Peculiarities of normative monetary valuation of land on the basis of spatial analysis]. Visnyk KhNAU. Seriia: Ekonomichni nauky - Bulletin of KhNAU. Series: Economic Sciences, 6, (pp. 31-37). Retrieved from http://nbuv. gov.ua/UJRN/Vkhnau_ekon_2014_6_8 [in Ukrainian].

9. Martyn, A.H. (2011). Aktualizatsiia pokaznykiv normatyvnoi hroshovoi otsinky zemel silskohospodarskoho pryznachennia [Actualization of indicators of normative monetary valuation of agricultural lands]. Zemlevporiadnyk visnyk - Land bulletin, 6, (pp. 32-37) [in Ukrainian].

10. Mekheda, N. \& Bakashev, Sh. (2011). Znachennia otsinky zemel yak resursnoho potentsialu [The value of land valuation as a resource potential]. Prydniprovskyi naukovyi visnyk - Dnieper Scientific Bulletin, 28 [in Ukrainian].

11. Nakaz Derzhavnoi sluzhby Ukrainy z pytan heodezii, kartohrafii ta kadastru Pro zatverdzhennia Polozhennia pro Holovne upravlinnia Derzhheokadastru u Mykolaivskii oblasti: vid 12.11.2019 № 285 [Order of the State Service of Ukraine for Geodesy, Cartography and Cadastre On approval of the Regulations on the Main Department of the State Geocadastre in Mykolaiv region: dated 12.11.2019 № 285]. mykolaivska.land.gov.ua. Retrieved from http:// mykolaivska.land.gov.ua/about [in Ukrainian].

12. Nakaz Ministerstva ahrarnoi polityky ta prodovolstva Ukrainy Pro zatverdzhennia Poriadku normatyvnoi hroshovoi otsinky zemel naselenykh punktiv: vid 25.11.2016 № 489 [Order of the Ministry of Agrarian Policy and Food of Ukraine On approval of the Procedure for normative monetary valuation of lands of settlements: dated 25.11.2016 № 489]. zakon.rada.gov.ua. Retrieved from https://zakon.rada.gov.ua [in Ukrainian].

13. Nakaz Ministerstva ahrarnoi polityky ta prodovolstva Ukrainy Pro zatverdzhennia Poriadku normatyvnoi hroshovoi otsinky zemel nesilskohospodarskoho pryznachennia (krim zemel naselenykh punktiv): vid 22.08.2013 № 508 [Order of the Ministry of Agrarian Policy and Food of Ukraine On approval of the Procedure for normative monetary valuation of non-agricultural lands (except lands of settlements): dated 22.08.2013 № 508]. zakon.rada.gov.ua. Retrieved from https://zakon.rada.gov.ua [in Ukrainian]. 
14. Nakaz Ministerstva ahrarnoi polityky ta prodovolstva Ukrainy Pro zatverdzhennia Poriadku normatyvnoi hroshovoi otsinky zemel silskohospodarskoho pryznachennia: vid 23.05.2017 № 262 [Order of the Ministry of Agrarian Policy and Food of Ukraine On approval of the Procedure for normative monetary valuation of agricultural land: from 23.05.2017 № 262]. zakon.rada.gov.ua. Retrieved from https://zakon.rada.gov.ua/laws/show/z0679-17 [in Ukrainian].

15. Novakovskii, L.Ia. (2015). Natsionalna dopovid shchodo zavershennia zemelnoi reformy [National report on the completion of land reform]. Kyiv: Ahrar. Nauka - Kyiv: Agrarian science [in Ukrainian].

16. Okrepka, A.I. (2012). Otsinka zemel yak pravovyi instytut zemelnoho prava Ukrainy [Estimation of lands as a legal institute of land law of Ukraine]. Aktualni problemy prava: teoriia i praktyka - Actual problems of law: theory and practice, 25, (pp. 429-436) [in Ukrainian].

17. Podatkovyi kodeks Ukrainy vid 02.12.2010 roku № 2755-VI [Tax Code of Ukraine dated 02.12.2010 № 2755-VI]. (2011). Vidomosti Verkhovnoi Rady Ukrainy - Bulletin of the Verkhovna Rada of Ukraine, 13, 13-14, 15-16, 17 [in Ukrainian].

18. Postanova Kabinetu Ministriv Ukrainy Deiaki zakhody shchodo pryskorennia reform u sferi zemelnykh vidnosyn: vid 16 lystopada 2020 r. № 1113 [Resolution of the Cabinet of Ministers of Ukraine Some measures to accelerate reforms in the field of land relations: from November 16, 2020 № 1113]. zakon. rada.gov.ua. Retrieved from https://zakon.rada.gov.ua [in Ukrainian].

19. Postanova Kabinetu Ministriv Ukrainy Pro Derzhavnu sluzhbu Ukrainy z pytan heodezii, kartohrafii ta kadastru: vid 14.01.2015 roku № 15 [Resolution of the Cabinet of Ministers of Ukraine On the State Service of Ukraine for Geodesy, Cartography and Cadastre: dated 14.01.2015 № 15]. (2015). Ofitsiinyi visnyk Ukrainy - Official Gazette of Ukraine, 7, st. 79 [in Ukrainian].

20. Postanova Kabinetu Ministriv Ukrainy Pro provedennia zahalnonatsionalnoi (vseukrainskoi) normatyvnoi hroshovoi otsinky zemel silskohospodarskoho pryznachennia ta vnesennia zmin do deiakykh postanov Kabinetu Ministriv Ukrainy: vid vid 7 liutoho 2018 r. № 105 [Resolution of the Cabinet of Ministers of Ukraine On conducting a national (all-Ukrainian) regulatory monetary valuation of agricultural land and amending some resolutions of the Cabinet of Ministers of Ukraine: from February 7, 2018 № 105]. zakon. rada.gov.ua. Retrieved from https://zakon.rada.gov.ua [in Ukrainian]. 
21. Postanova Kabinetu Ministriv Ukrainy Pro vnesennia zmin do Metodyky normatyvnoi hroshovoi otsinky zemel silskohospodarskoho pryznachennia ta naselenykh punktiv: vid 31.10.2011 roku № 1185 [Resolution of the Cabinet of Ministers of Ukraine On Amendments to the Methodology of Normative Monetary Valuation of Agricultural Lands and Settlements: dated 31.10.2011 № 1185]. (2011). Ofitsiinyi visnyk Ukrainy - Official Gazette of Ukraine, 90, st. 31 [in Ukrainian].

22. Postanova Kabinetu Ministriv Ukrainy Pro zatverdzhennia Metodyky normatyvnoi hroshovoi otsinky zemel nesilskohospodarskoho pryznachennia (krim zemel naselenykh punktiv): vid 23.11.2011 roku № 1278 [Resolution of the Cabinet of Ministers of Ukraine On approval of the Methodology of normative monetary valuation of non-agricultural lands (except for lands of settlements): dated 23.11.2011 № 1278]. (2011). Ofitsiinyi visnyk Ukrainy Official Gazette of Ukraine, 97, st. 138 [in Ukrainian].

23. Postanova Kabinetu Ministriv Ukrainy Pro zatverdzhennia Metodyky normatyvnoi hroshovoi otsinky zemel silskohospodarskoho pryznachennia: vid 16.11.2016 roku № 831 [Resolution of the Cabinet of Ministers of Ukraine On approval of the Methodology of normative monetary valuation of agricultural lands: dated 16.11.2016 № 831]. (2016). Ofitsiinyi visnyk Ukrainy - Official Gazette of Ukraine, 93, st. 131 [in Ukrainian].

24. Solovianenko, N. (2016). Otsinka zemel: teoriia, metodolohiia, praktyka [Land valuation: theory, methodology, practice]. Zemlevporiadnyi visnyk Land bulletin, 7, (pp. 36-41) [in Ukrainian].

25. Solovianenko, N. (2016). Otsinka zemel: teoriia, metodolohiia, praktyka [Land valuation: theory, methodology, practice]. Zemlevporiadnyi visnyk Land bulletin, 8, (pp. 26-30) [in Ukrainian].

26. Standart Derzhavnoho komitetu Ukrainy iz zemelnykh resursiv «Otsinka zemel. Pravyla rozroblennia tekhnichnoi dokumentatsii z normatyvnoi hroshovoi otsinky zemel naselenykh punktiv» [Standard of the State Committee of Ukraine for Land Resources «Land valuation. Rules for the development of technical documentation for the normative monetary valuation of lands of settlements»]. (2009). SOU DKZR 0032632-012:2009. Retrieved from http://www.normative.org.ua/index.php/korysna-informatsiia-b/6-standart-derzhkomzemu-otsinka-zemel [in Ukrainian].

27. Stepenko, O.V. (2013). Heoinformatsiine zabezpechennia hroshovoi 
otsinkyzemelnykhresursiv[Geoinformation supportofmonetaryvaluation ofland resources]. K.R. Tretiak (Eds.), Heodeziia, kartohrafiia i aerofotoznimannia Geodesy, cartography and aerial photography: interdepartmental scientific and technical collection Mizhvidomchyi naukovo-tekhnichnyi zbirnyk. Ministry of Education and Science, Youth and Sports of Ukraine, National University «Lviv Polytechnic», 77. Lviv: Lviv Polytechnic Publishing House. Retrieved from http://ena.lp.edu.ua:8080/handle/ntb/19743[in Ukrainian].

28. Zakon Ukrainy Pro Derzhavnyi zemelnyi kadastr: vid 07.07.2011 № 3613-VI [On the State Land Cadastre: Law of Ukraine of 07.07.2011 № 3613VI]. (2012). Vidomosti Verkhovnoi Rady Ukrainy - Bulletin of the Verkhovna Rada of Ukraine, 8, st. 61 [in Ukrainian].

29. Zakon Ukrainy Pro otsinku zemel: vid 11.12.2003 roku № 1378-IV [On land valuation: Law of Ukraine of 11.12.2003 № 1378-IV]. (2004). Vidomosti Verkhovnoi Rady Ukrainy - Bulletin of the Verkhovna Rada of Ukraine, 15, st. 229.44 [in Ukrainian].

30. Zemelnyi kodeks Ukrainy [Land Code of Ukraine]. (2019, January 24). Kharkiv: Pravo [in Ukrainian].

\section{Відомості про авторів / Information about the Author}

Малиновська Наталя Леонідівна: Чорноморський національний університет імені Петра Могили: вул. 68 десантників, 10, м. Миколаїв, 54003, Україна.

Natalia Malynovska: Black Sea National University of Petro Mohyla, 68 Desantnykiv str. 10, Mykolaiv, 54003, Ukraine

\section{ORCID.ORG/ 0000-0003-0861-603X}

\section{E-mail: chdunatali@meta.ua}

Штирьов Олександр Миколайович: Чорноморський національний університет ім. Петра Могили: вул. 68 десантників 10, м. Миколаїв, 54003, Україна. 
Oleksandr Shtyrov: Petro Mohyla Black Sea National University: 68 Desantnykiv str. 10, Mykolaiv, 54003, Ukraine.

ORCID. ORG./ 0000-0002-7627-3721

\section{E-mail: bratislava@ukr.net}

Головащенко Наталія Григоріївна: Головне управління Держгеокадастру у Миколаївській області: вул. Миру, 34, м. Миколаїв, 54034, Україна.

Nataliia Holovashchenko: Main Directorate of the State Geocadastre in the Nikolaev region: Peace Avenue 34, Mykolaiv, 54034, Ukraine.

E-mail: mykolaiv-rynok@land.gov.ua 